\title{
қҰҚық
}

\section{UDC 342.2}

МРНТИ 10.07.01

DOI: https://doi.org/10.37788/2021-1/ 50-56

\author{
Zh.B. Amanbai \\ Innovative University of Eurasia, Pavlodar c., Kazakhstan \\ (e-mail: zhanel.amanbai@mail.ru)
}

\section{Economic interests of the Republic of Kazakhstan as a state-legal institution: the concept and problems of implementation}

\begin{abstract}
Annotation
Main problem: in the history of mankind there are many examples when the question of national interests remains unresolved. The category of "national interest" has firmly entered the modern political and scientific spheres of all countries of the world. Regardless of the level and nature of development, any country has certain national interests on which it should focus. Undoubtedly, these are economic interests. Future populations, whose state and national goals are not clearly defined, may be unplanned and fragmented. Consequently, it may be violently imposed on a foreign socio-political structure. Historical experience shows that the staging of specific problems can have a negative impact on the application and implementation of the necessary measures to prevent possible mistakes, to strengthen the security of the country. In order to make this article complete and exhaustive, it is necessary to pay attention to the concept of "concept", which reflects the active attitude of people to the surrounding world as the most important category.

Purpose: The purpose of the study is to analyze the concept of economic security as a state-legal institution in the Republic of Kazakhstan.

Methods: The following methods are used in the article: comparative-legal, system-structural, as well as the method of systematic analysis of needs.

Results and their significance: Necessity, personal interests are one of the key links in the study of the essence of the social state. After all, the rule of law in its norms must express the social interests of man in life. These categories are intended to identify the indirect causes of social actions that lead to changes and additions in various spheres of public life. Every country has its own attractions. Interests are different. And the social group, and the team, and the individual combine their actions with their interests. Man interacts with it through its goal, which determines the interests of the environment. Therefore, at the level of common consciousness, a great value of interest is determined by individual actions and actions of people, as well as by mass historical events and phenomena.

By looking at this issue in detail and analyzing its basic principles, we define the concept of economic interest. In order to ensure the economic security of Kazakhstan, it is necessary to rely on its own scientific and technological development, human and natural resources, that is, to decide on management in favor of domestic producers and ensure capital investment in priority sectors of the economy.
\end{abstract}

Keywords: public interest, state, national, economic interests, energy and raw materials.

\section{Introduction}

Political power cannot strengthen its authority if it does not adhere to the system of state, national, economic interests and goals that the vast majority of the population understands and accepts. Contributing to the sustainable development of society, based on national interests and values, stops the decline of public administration and the decline of the social status of the population, and succeeds in combating corruption and organized crime. To understand national interests and the mechanism for their implementation, it is necessary to take into account two basic principles.

\section{Materials and methods}

Given that the methodological basis of the study is the traditional general scientific and special legal methods used in comparative jurisprudence, strategic and tactical, systemic-structural, socio-legal and comparative law: substantiated by privatization, shows that trade can not be found only on the world market. Today's direction of the authorities is energy and raw materials, ie the development of the country is based on the export of raw materials and imports of consumer goods. Such a trend will lead to the decline of domestic industry and agricultural production, financial imbalances, the crisis of science, the decline in living standards and quality of life of the vast majority of the population, rising unemployment and crime, increasing social tensions in society.

The second view is that the national interests of the country are the openness of society and the need to maintain the achieved level of civil liberties, a wide range of consumer goods, a socially oriented economy, 
premature modernization based on new streams of science-based industries and technologies should be connected. This trend is objectively related to the unification of a number of independent CIS states and Kazakhstan's entry into the world market.

\section{Results}

Typically, the scheme of the national security process involves the implementation of several (sequential) operations: first the national interests, then - the actual and potential threats to these interests are identified, and only then the threat prevention or neutralization, ie national security policy is formed [1; 34]. Thus, the definition of national interests has not only theoretical and methodological significance, but also an important practical role. All this means that the concept of "national interest" is important in the creation of individual and general problems of national security, as well as in its practical implementation. This situation requires a detailed consideration of the essence and content of national interests and their relationship. The relevance of this is that the methods of solving this problem are different both in the scientific literature and in the relevant official documents of the Republic of Kazakhstan.

In general, the need to protect national interests is usually at the heart of ensuring the national security of virtually all countries in the world. Such an indisputable interrelation of these two concepts has created a kind of "cautionary" approach to the problems of national security. It should be noted that such an approach to defining the essence of security is also prevalent in Kazakhstan's political literature. The most important reference in this case is given in the Law of the Republic of Kazakhstan of June 26, 1998 "On National Security of the Republic of Kazakhstan", so it is the main one. This Law states that the security of the Republic of Kazakhstan is a state of protection of the national interests of the country from real and social threats. In the definition in question, security is associated with the protection of national interests, and in fact is completely "summarized" by the same concept. The goals of security and protection of the country's interests are not specified. The preamble of the law states only that "ensuring national security" is a key condition for the development of the Republic of Kazakhstan as an independent, sovereign state.

In our opinion, it is not accidental that the provisions of Kazakhstan's legislation on the relationship between national security and national interests are insignificant. It is due to insufficient study of the concept of "national interest" and related issues.Although the law is not a concept or strategy, the main drawback of such a mechanical approach to defining the concept of "national interest" is obvious.

In our case, it is necessary to find a broader and closer concept for the concept of "national interest", to bring it to this concept and to identify its species. Such a rule is enshrined in Article 1 of the Law of the Republic of Kazakhstan of June 26, 1998 "On National Security of the Republic of Kazakhstan." It states that the "national interests of the Republic of Kazakhstan" are a set of political, economic, social and other needs of the Republic of Kazakhstan, the implementation of which depends on ensuring the protection of constitutional rights of man and citizen, the values of Kazakhstani society.

Based on the above, we would like to define the concept of "national interest" as follows. The national interest is the need of the people, which must be met and protected in order to ensure the safe existence, effective functioning and development of the country, which is felt by the subjects of public policy. It is through this approach that the essence, purpose and content of public policy, the need to analyze many different facts, statements, declarations, programs, as well as all the specific economic, political and other measures taken.

First of all, after understanding the needs and defining the essence of the national interest, their classification is carried out. It can be created on different bases in terms of significance, scope, duration, spheres of public life.In essence, the national interest can be divided into vital, important and simple interests . The spheres of vital interests, as a rule, include state sovereignty and independence of the country, territorial integrity and stability of borders, inviolability of constitutional institutions, etc. enters. The list of important interests includes respect for human rights, peace and development of the country, public safety, interethnic stability, etc. can be attributed. Ordinary interests usually include secondary interests, such as environmental, spiritual, cultural and other security.

By their scope, national interests are usually divided into fundamental, strategic and tactical interests. Respectively, long-term and short-term interests are usually distinguished by the duration of the interest. National interests are reflected in public life by specific types of interests: economic, political, military, social, etc. is classified as It should be noted that such a classification of national interests is mandatory, because otherwise the procedure for determining national interests can become a simple list of all the problems of society. Thus, the protection of the national interests of the country is a key and connecting factor in ensuring the national security of Kazakhstan. Given these circumstances, in studying the problems of national security of Kazakhstan, in terms of protecting its national interests, it is expedient to adhere to the principle that national interests are a category of security policy that reflects the needs of the country. At the same time, the national interests of Kazakhstan arise from the general and political features of the country, as well as the place and role of the Republic of Kazakhstan in the system of international relations.

Adaptation of the country's economy to the market will lead to a sharp decline in real incomes, increased social stratification in terms of income, consumption, access to essential material services and an increase in the number of families living below the poverty line.

As mentioned above, in addition to the social basis, economic interests also have a material basis with some degree of indirect economic relations in the form of needs. There is still no consensus in the economic 
literature on the relationship between needs and interests. Some researchers consider interests to be a target function of needs [2; 25] or a manifestation of conscious needs [3; 132].

Recognizing the differences in needs and interests in the first case, the author gave a separate description of the state of material life of these two categories of society. Here the needs are not only the command of production, but also its product. And interests are only a prerequisite for the development of production. The functional role of needs and interests as a protective factor of production is also different, according to this view, interests adapt to the goal, reflecting the movement of their individual subjects or groups, and needs describe the state of the material region of those subjects. Despite the attractiveness and productivity of such an approach, it regulates the relationship of interests and needs to cause and effect. It is known that man and society act in accordance with their economic interests to meet certain needs. This determines the cause-andeffect relationship between needs and interests, so that the former is the material basis of the latter [4; 69].

The second approach leads to a certain balance of needs and economic interests, so that both categories are closely linked with production and consumers. In addition, this approach provides a basis for classifying economic interests into subjective categories, as equating needs with interests, which makes the presence of interests at different levels of social structure dependent on the quality or poor quality of needs.

In fact, conscious need becomes the purpose of this activity, justifies the activities of each subject of economic relations, makes the categories of "interest" and "need" indistinguishable from each other, the difference between them is a subjective factor - only the perception of needs. It seems that such an approach would be vulnerable to addressing the nature of economic interests.

At the same time, many researchers believe that economic interests and needs are the relationship of objects in an objective form, which arises in the course of the activities of the subjects of this type of relationship $[5 ; 305]$. But only the inclusion of interdependent subjects of human activity in the process of production, distribution, exchange and consumption in order to meet needs creates some economic interests. Thus, economic interests act as an indirect link between the needs of the subjects and their production and other social practices $[6 ; 147]$, that is, the need for social and historical reason. Needs, in turn, form the material basis of economic interests, as interests arise not in the sense of perception, but in the process of specific actions aimed at meeting needs.

This approach seems to us to be the best and most convincing:

1. It reflects the dependence and derivation of interests from such objective needs and economic relations.

2. Interest is expressed not as a result of subjective desires that turn social development into a random process, but as a factor justifying this development, thereby affecting the lives of peoples.

3. Management of the economic process finds an objective basis for the mechanism, one of the central links of which is the economic interest.

4. The objectivity of interests reflects the discovery of the relationship between economic relations and their subjects, which is the basis for reconciling interests, finding ways to resolve the unavoidable contradictions between them in their various forms.

Interests indirectly promote economic activity and promote the implementation of economic laws in practice, which allows them to be classified as a mechanism of legal implementation [7; 352]. Any law is not considered outside the interests, with which the law is functionally and genetically related, because the interests and laws are based on economic relations. The problem of interests in the application of laws in the field of economics has been studied in more depth. There is a lack of research by domestic scientists on the laws related to market relations, as well as the demand, supply and competition for them. As a result, there are a number of shortcomings in the implementation of economic reforms in the country, including at the regional level. According to a number of scholars studying the legal field of the country, success can be achieved only on the basis of objective legislation and reliable representation of public interests, defining and clearly defining the goals of economic development, developing a strategy to change the industry to bring it in line with modern competitive countries.

At the same time, the objectivity of the nature of economic laws and economic interests does not mean that they do not change, because the interests within each mode of production, and especially outside them, change over time under the influence of needs and changing economic relations. market changes.

Due to the complexity of the relationship between economic laws and interests, it is necessary to separate them. We are limited to the principle that the formation of a market economy, the crisis situation of the economic system as a whole, as well as the separate consideration of laws in terms of individual problems and structural components, their effective implementation outside the system of economic interests [8].

There is no definite position in the economic literature on the form and manifestation of economic interests. In some studies, their appearance and performance are equated with any economic practice. According to such notions, various forms of incentives, financial performance are the real manifestation of economic interests. The description of the categories of incentives is not the same as the interests themselves. The concept of general incentives and interests has a balanced meaning, and the incentive itself is interpreted as an objective basis of economic interests [6;147-148].

In our opinion, the method we explain in the materialist analysis of the social process reflects the deep logical connection between the categories that determine it, the objective consistency in economic life. Thus, it 
must be acknowledged that economic interests arise and are fulfilled, and incentives are the most important form of their implementation.

The goals of economic incentives will be different. Through incentives, one entity of interest influences another, using various economic methods such as pricing, wages, lending, remuneration, management, taxation, and so on.

Economic interests are the interests of production, the main part of the public consumption fund. It should be noted that in recent years, various stages of social development of the republic have found their place $[8 ; 16]$. Economic interests are seen as a certain system, which is directly related to a number of factors. To them: economy;

- characterized by the interests of the subjects of the existing system of division of labor in the national

- is reflected in the definition and coordination of interests in the general system of state law;

- one-sided nature of ethno-social behavior and development priorities in the public consciousness.

\section{Discussion}

In a crisis economy, the need to identify and describe the system of economic interests and its key components is especially relevant. There are several methodological approaches to justifying the system of interests in economic and legal research for economic interests.

We have several types and forms of interest in society. This clearly shows the connection between their relationship with property. In terms of the type of general economic interests, it corresponds to the interests of society, regions, certain labor collectives, which represent the actual existing relations of common property. The state and results of production correspond to a wide range of interests in private property from the individual entrepreneur to the employee. Within these species there is a variety of forms. For example, our study can be seen in a comprehensive analysis of the interests of regions with different shares of state or non-state property, and the interests of diversity, such as the interests of industrial and recreational regions within these forms.

In fact, this shows that the structure of economic interests is related to the transformation of the structure of economic relations in society to the general nature of interests and its dependence on changes in the economic system. Such a methodological approach to the theory of economic interest has a special place for the application of subjects in a market economy.

A multi-structured economy defines two types of property. They show the existence of private and state property, as enshrined in the Constitution of the Republic of Kazakhstan [9;3]. In the context of our study, we would like to dwell more on regional economic interests.

As mentioned earlier, in the scientific literature, the region is a concept of accumulation, with it often at the level of the administrative division of the Republic of Kazakhstan, territorial and economic space; the space of the largest economic regions of the country, as well as areas with their own functions that form part of the territory of the administrative division. Until recently, these differences were recognized as a territorial structure, the definition of which in the conditions of market changes was supplemented by a number of qualitative characteristics of an economic nature. As a result, describing the region, we can consider several of its characteristics:

- as one of the main subjects of economic relations in times of crisis;

- the region is a part of political, territorial, economic integrity, which is called a single state;

- it is a structure for the organization of large or small business activities;

- it is a structure with different needs, determined by its production, social, demographic characteristics and place in the national division of labor;

- it is a structure with qualitatively known economic interests, the specificity of which is determined by the economic relations, needs and functions that are formed here.

From the above it can be said that the concept of "region" is a territorial-geographical, ecological, industrial and socio-economic system of economic integrity, which provides the process of social reproduction in different forms.

In our opinion, any other approach that limits the understanding of the region, such as the territorial organization of production, division of labor, the territorial system of the economy, will be limited.

In the course of the study, we noticed that it was impossible to separate the economic interests of the region.

Ensuring rapid economic growth is one of the mechanisms to address the above issues. After all, the state tries to implement all possible economic mechanisms in order to ensure sustainable economic growth $[10 ; 175]$.

Research shows that the way to resolve these contradictions in a market environment is to reconcile through economic mechanisms, which arise from the legal balance of economic interests. Of course, this principle also applies to the regions and their economic relations with each other and with the internal regional administrative and economic structures.In connection with the change of the market economy, it is possible to divide the regional economic interests into economic categories in the formation of the regions as specific subjects of economic relations.

Realization of oil interests is possible only through the systematic organization of economic relations, which in turn is interpreted as a set of norms, mechanisms, forms of principles of unity, regional and local self- 
government, the principles of market economy, which are economic, social, The link between environmental and other interests. One of the most important systemic tools is the establishment of generally accepted links in the public consciousness of the systematic organization of economic relations. First of all, there are property relations. These include: economic relations in the field of land, fiscal, natural resources and economic regulation, and other legal relations at the state, regional and local levels. The main problem in the formation of such a regional policy is the formation of regional economic interests individually and its recognition as a certain qualitative form of common interests in the formation of a variety of property relations. It defines not only the objects within the regions, but also the legal status of the regions, as well as the basis of ownership.

\section{Conclusion}

As mentioned earlier, privatization takes the form of contradictions. Conflicts of economic interests are reflected in the different needs of the regions as a material basis. Striving to achieve sustainable economic development common to all regions, the balance of access to and use of resources, the effectiveness of the use of available resources, the achievement of a favorable level of social development, measured by living standards, etc. is. Each region has its own place in the system of social division of labor, has its own characteristics of the natural, economic, social situation, and therefore has certain characteristics of needs and opportunities. This feature often predetermines the place of the region in the social division of labor and its very convincing production and economic status.

At the same time, these conditions affect the process of realization of economic interests, the resolution of their inherent contradictions, which is one of the interests that take place within the regional structures.

Both objective and subjective factors can affect the economic security of the state. For example, the activities of international political and economic organizations, foreign states, special services, large firms and corporations, and high-ranking individuals. Economic issues are often closely linked to political issues (power struggles).

Economic security is directly dependent on the following services:

- quality of life of different groups of the population;

- Who owns the property, how the privatization process is going;

- actual unemployment rate;

- level of socio-political tension (regional, local conflicts and strikes);

- Qualifications of officials of different levels. interest.

By looking at this issue in detail and analyzing its basic principles, we define the concept of economic

In order to ensure the economic security of Kazakhstan, it is necessary to rely on its own scientific and technological development, human and natural resources, that is, to decide on management in favor of domestic producers and ensure capital investment in priority sectors of the economy.

In conclusion, it should be noted that economic interests play a relevant and fundamental role in ensuring the economic security of the Republic of Kazakhstan, as the status of Kazakhstan depends on the results of the country's economic development.

\section{THE LIST OF SOURCES}

1 Митрохин С.С. Политика государства и ценности общества / С.С. Митрохин // Полис: Политические исследования. - 1997. - № 1. - С. 34-36.

2 Манилов В.Л. Безопасность в эпоху партнерства / В.Л. Манилов. - М.: Терра, 1999. - 362 с.

3 Мамедов О.Ю. Производственное отношение: Политико-экономическая модель: Материалы к спецкурсу / О.Ю. Мамедов. - Ростов-на-Дону, 1997 - 282 с.

4 Гершкович Б.Я. Концепция экономических интересов в условиях реформирования российской экономики / Б.Я. Гершкович // Научная мысль Кавказа. - 1996. - № 1. - С.69-77.

5 Экономическая теория. Задачи, логические схемы, методические материалы / Под ред. А.И. Добрынина, Л.С. Тарасевича. - СПб., 1999. - 448 с.

6 Генкин А. Система экономических интересов и социальная гармония / А. Генкин // Вопросы экономики. - 1993. - № 6. - С. 147-148.

7 Дидро Д. Избранные произведения / Д. Дидро. - Ленинград: Гослитиздат, 1951. - 412 с.

8 Бисеконов О. Еліміздің экономикалық қауіпсіздігін қамтамасыз етудің өзекті мәселелері / О. Бисеконов // Заң. - 2010. - № 9. - С. 16-17.

9 Агеев В.М. Интересы, Стимулы, Эффективность / В.М. Агеев. - М.: МГУ, 1974. - 41 с.

10 Политическая экономия / Под ред. О.И. Ожерельева. - М.: Политиздат, 1990. - 607 с.

\section{REFERENCES}

1 Mitrohin, S.S. (1997). Politika gosudarstva i cennosti obshchestva [Politics of the state and values of society]. Polis: Politicheskie issledovaniya - Polis: Political studies, 1, 34-36.

2 Manilov, V.L. (1999). Bezopasnost' v epohu partnerstva [Security in the era of partnership]. - Moscow: Terra. 
3 Mamedov, O.Yu. (1997). Proizvodstvennoe otnoshenie: Politiko-ekonomicheskaya model': Materialy k speckursu [Production attitude: Political and economic model: Materials for a special course]. Rostov-on-Don. 4 Gershkovich, B.Ya. (1996). Koncepciya ekonomicheskih interesov v usloviyah reformirovaniya rossijskoj ekonomiki [The concept of economic interests in the conditions of reforming the Russian economy]. Nauchnaya mysl' Kavkaza - Scientific thought of the Caucasus, 1, 69-77.

5 Dobrynin, A.I., Tarasevich, L.S. (Eds.). (1999). Ekonomicheskaya teoriya. Zadachi, logicheskie skhemy, metodicheskie materialy [Tasks, logical schemes, methodological materials]. Saint Petersburg.

6 Genkin, A. (1993). Sistema ekonomicheskih interesov i social'naya garmoniya [System of economic interests and social harmony]. Voprosy ekonomiki - Economic issues, 6, 147-148.

7 Didro, D. (1951). Izbrannye proizvedeniya [Selected works]. Leningrad. Goslitizdat.

8 Bisekonov, O. (2010). Elimizdin ekonomikalyk kauipsizdigin kamtamasyz etudin ozekti maseleleri [Actual problems of ensuring the country's economic security]. Zan - Law, 9, 16-17.

9 Ageev, V.M. (1974). Interesy, Stimuly, Effektivnost' [Interests, Incentives, Efficiency]. Moscow. MGU.

10 Ozherel'ev, O.I. (Eds.). (1990). Politicheskaya ekonomiya [Political Economy]. Moscow. Politizdat.

\section{Ж.Б. Аманбай}

Инновациялық Еуразия университеті, Қазақстан

\section{Қазақстан Республикасының Мемлекеттік-құқықтық институт ретіндегі экономикалық мүдделері: іске асыру ұғымы және проблемалары}

Адамзат тарихында ұлттық мүдде туралы мәселенің шешім таппауына байланысты мысалдар аз емес. «Ұлттық мүдде» санаты әлемнің барлық мемлекеттерінің қазіргі заманғы саяси және ғылыми салаларға мықтап енді. Дамуының дәрежесі мен сипатына қарамастан кез келген елдің белгілі бір баса назар аударатын ұлттық мүдделері бар. Олардың қатарына экономикалық мүдде кіретіні даусыз. Мемлекеттік-ұлттық мақсаттары нақты айқындалмаған халықтың болашағы жоспарсыз, шашыраңқы болуы мүмкін. Сол себепті, оған жат әлеуметтік-саяси құрылым күштеп таңылуы мүмкін. Тарихи тәжірибе көрсетіп отырғандай, нақты проблемаларды боямалау, мүмкін боларлық қателердің алдын алу, мемлекет ішінде қауіпсіздікті нығайту жөніндегі қажетті шараларды қолдану мен өткізуге кері әсерін тигізуі мүмкін. Осы мақаланы толық мәнді және жан-жақты ету үшін біз аса маңызды категория ретінде адамдардың оларды қоршаған әлемге белсенді қатынасын көрсететін «концепт» ұғымына соқпай өте алмаймыз.

Зерттеудің мақсаты - Қазақстан Республикасындағы мемлекеттік-құқықтық институт ретінде экономикалық қауіпсіздік ұғымын талдау болып табылады.

Мақалада келесі әдістер қолданылды: қажеттілік салыстырмалы-құқықтық, жүйелікқұрылымдық, сонымен қатар жүйелік талдау әдісі.

Қажеттілік, тұлғаның мүдделері әлеуметтік мемлекеттің мәнін зерттеуде - басты буындардың бірі болып табылады. Өйткені, құқықтық мемлекет өз нормаларында тұлғаның өмірдегі әлеуметтік мүдделерін сол қалпында білдіруі тиіс. Осы категориялар әлеуметтік әрекеттердің тікелей себептерін ашуы үшін жасалған, соның нәтижесінде қоғамдық өмірдің түрлі саласында өзгерістер мен толықтырулар болып тұрады. Әрбір елде мүдденің алатын орны ерекше. Мүдделер әртүрлі болып келеді. Әлеуметтік топ та, ұжым да, тұлға да өз қылықтарының, әрекеттерін өз мүдделерімен ұштастырады. Адам оны қоршаған ортаға қажетті мүдделерді анықтайтын өз мақсаты арқылы бірлесе іс-қимыл жасайды. Сондықтан әдеттегі сана деңгейінде адамдардың жеке іс қимылы мен қылықтарында, сондайақ жаппай тарихи оқиғалар мен құбылыстарда мүдденің үлкен мағынасы айқындалады.

Осы мәселені егжей-тегжейлі қарастырып, оның негізгі принциптерін талдай отырып, біз экономикалық қызығушылық ұғымын анықтаймыз. Қазақстанның экономикалық қауіпсіздігін қамтамасыз ету мақсатында өзіндік ғылыми-техникалық дамуға, адами және табиғи ресурстарға сүйену, яғни отандық өндірушілердің пайдасына басқару туралы шешім қабылдау және экономиканың басым салаларына күрделі салымдарды қамтамасыз ету қажет.

Түйін сөздер: қоғамдық мүдде, мемлекеттік, ұлттық, экономикалық мүдделер, энергетика, шикізат.

\section{Ж.Б. Аманбай}

Инновационный Евразийский университет, Казахстан

\section{Экономические интересы Республики Казахстан как государственно-правовой институт: понятие и проблемы реализации}

В истории человечества есть множество примеров, когда вопрос национальных интересов остается неразрешенным. Категория «национальный интерес» прочно вошла в современную политическую и научную сферы всех стран мира. Независимо от уровня и характера развития у любой страны существуют определенные национальные интересы, на которых необходимо сосредоточиться. 
Несомненно, это экономические интересы. Будущее населения стран, где государственные и национальные цели четко не определены, может быть незапланированным и фрагментарным. Следовательно, ему может быть насильственно навязана иностранная общественно-политическая структура. Исторический опыт показывает, что постановка конкретных проблем может негативно сказаться на применении и реализации необходимых мер по предотвращению возможных ошибок, укреплению безопасности внутри страны. Для того чтобы данное исследование было полным, необходимо рассмотреть понятие «концепт», которое отражает активное отношение людей к окружающему миру как важнейшую категорию.

Целью исследования является анализ понятия экономической безопасности как государственноправового института в Республике Казахстан. В статье использованы сравнительно-правовой, системноструктурный методы, метод систематического анализа потребностей.

Необходимость, интересы личности - одно из ключевых звеньев в изучении сущности социального государства, ведь верховенство закона в своих нормах должно выражать социальные интересы человека в жизни. Эти категории предназначены для выявления непосредственных причин социальных действий, приводящих к изменениям и дополнениям в различных сферах общественной жизни. Каждому государству присущи свои характерные особенности. При этом и социальная группа, и команда, и отдельный человек совмещают свои действия со своими интересами. Человек взаимодействует с ней через свою цель, которая определяет интересы окружающей среды. Следовательно, на уровне обыденного сознания большое значение интереса определяется как отдельными действиями и поступками людей, так и массовыми историческими событиями и явлениями.

Ключевые слова: общественный интерес, государство, национальные, экономические интересы, энергетика и сырье.

Date of receipt of the manuscript to the editor: $2021 / 02 / 25$ 